\title{
Potensi Disinfektan sebagai Sediaan Kebiri Kimiawi pada Ternak
}

\author{
Lena Indraswari ${ }^{1}$, Siti Sa'diah ${ }^{2}$, Mokhamad Fakhrul Ulum ${ }^{3, \text { a }}$ \\ ${ }^{I}$ Program Pendidikan Profesi Dokter Hewan; Fakultas Kedokteran Hewan; Institut Pertanian Bogor \\ ${ }^{2}$ Departemen Anatomi, Fisiologi, dan Farmakologi; Fakultas Kedokteran Hewan; Institut Pertanian Bogor \\ ${ }^{3}$ Departemen Klinik, Reproduksi, dan Patologi; Fakultas Kedokteran Hewan; Institut Pertanian Bogor \\ Jl. Agatis, Kampus IPB Dramaga, Bogor, Jawa Barat, 16680, Indonesia \\ a)email: ulum@ipb.ac.id
}

\begin{abstract}
Abstrak
Kastrasi kimiawi dapat digunakan sebagai alternatif dari kastrasi terbuka. Tujuan dari penelitian ini untuk menguji potensi bahan kimia disinfektan sebagai sediaan bahan kimia untuk kastrasi pada mencit. Penelitian ini menggunakan zat aktif disinfektan sebagai material kastrasi kimiawi pada mencit. Mencit jantan sebanyak 27 ekor berusia 2-7 bulan dengan bobot badan 28-42 g dibagi menjadi 7 kelompok: kloroxylenol 4,8\% $(\mathrm{C} 4, \mathrm{n}=4)$, povidon iodin $10 \%(\mathrm{P} 10, \mathrm{n}=4)$, kloroxylenol 2,4\% dan povidon iodin $5 \%$ $(\mathrm{C} 2 \mathrm{P} 5, \mathrm{n}=4)$, kloroxylenol 1,2\% dan povidon iodin $2,5 \%(\mathrm{C} 1 \mathrm{P} 2, \mathrm{n}=4)$, sodium hipoklorit 5,25\% $(\mathrm{S} 5, \mathrm{n}=4)$, $\mathrm{NaCl} 0,9 \%(\mathrm{~N}, \mathrm{n}=4)$, dan akuadestilata $(\mathrm{A}, \mathrm{n}=3)$. Disinfektan sebanyak 0,2 mL diinjeksi pada masingmasing testis pada setiap kelompok. Daya hidup mencit setelah kastrasi kimiawi pada kelompok perlakuan C4, C2P5, C1P2, kontrol A, dan kontrol N berada diantara 25-100\%. Populasi mencit mati 100\% dalam 24 jam pada kelompok perlakuan P10 dan S5. Kastrasi kimiawi menggunakan disinfektan (C4, C2P5, dan C1P2) menyebabkan penurunan ukuran testis; perubahan profil eritsosit, limfosit relatif, neutrofil relatif; dan menyebabkan struktur anekhoik pada jaringan testis 7 hari setelah kastrasi kimiawi dibandingkan dengan kontrol (A dan N). Kombinasi kloroxylenol 1,2\% dan povidon iodin 2,5\% dapat digunakan sebagai agen kastrasi kimiawi pada mencit.
\end{abstract}

Kata kunci: kastrasi kimiawi, mencit, kloroxylenol, povidon iodin, sodium hipoklorit

\section{Potential of disinfectants as chemical castration agent for livestock}

\begin{abstract}
Chemical castration can be used as an alternative of open castration. The purpose of this study was to determine the potential of disinfectants as chemical agent forcastration in mice. This study was used disinfectant as an active substance as chemical castration agent in mice. Twenty seven male mice aged 27 months with body weight 28-42 $\mathrm{g}$ were divided into 7 groups: chloroxylenol $4.8 \%(C 4, n=4)$, povidone iodine $10 \%(P 10 n=4)$, chloroxylenol $2.4 \%$ and povidone iodine $5 \%(C 2 P 5, n=4)$, chloroxylenol $1.2 \%$ and povidone iodine $2.5 \%(C 1 P 2, n=4)$, sodium hypochlorite $5.25 \%(S 5, n=4), \mathrm{NaCl} 0.9 \%(N, n=4)$, dan aquadest $(A, n=3)$. A $0.2 \mathrm{~mL}$ of the disinfectants were injected in each testis of the groups. The survival rate of mice after chemical castration in groups $C 4, C 2 P 5, C 1 P 2$, control $A$, and control $N$ were $25-100 \%$. However, 100\% mice were death 24 hours on the groups P10 and S5. Chemical castration using disinfectants (C4, C2P5, and C1P2) causes the size of testis decrease; changes in erythrocyte count, relative lymphocytes, relativeneutrophils; and causesanechoic area in the testical tissue 7 days after chemical castration compared to that control (A and $N$ ). The combination of $1.2 \%$ chloroxylenol disinfectant and $2.5 \%$ of povidone iodine solution potentially can be used as a chemical castration agent in mice.
\end{abstract}

Keywords: chemical castration, mice, chloroxylenol, povidone iodine, sodium hypochlorite 


\section{Pendahuluan}

Ternak potong umumnya adalah jenis ternak jantan non pemacek yang dipelihara untuk menghasilkan daging sebagai produk utamanya (Susilorini, et al., 2007). Masalah yang sering muncul pada pejantan non pemacek adalah libido dan kualitas semen yang rendah. Ternak jantan yang berkualitas rendah dapat berdampak negatif terhadap efisiensi reproduksi pada sapi-sapi induk yaitu angka konsepsi rendah (Ratnawati, et al., 2015). Ternak jantan yang tidak layak dijadikan pemacek umumnya dikastrasi dan dijadikan sebagai ternak potong (Talib, dkk., 2011; Kementan, 2014). Kastrasi merupakan salah satu cara yang dapat digunakan untuk meningkatkan bobot badan pada hewan ternak jantan dan mengatasi inbreeding (Praharani dan Sianturi, 2018). Hewan ternak yang dikastrasi akan cenderung jinak sehingga membantu konversi pakan menjadi daging lebih baik (Kuswati, et al., 2015). Inbreeding adalah salah satu jenis perkawinan yang dilakukan antara individu yang memiliki hubungan sedarah atau kekerabatan dekat. Inbreeding dapat terjadi karena beberapa faktor yaitu jumlah populasi atau ukuran populasi efektif yang kecil termasuk rasio pejantan dan betina produktif, perkawinan tidak terarah, dan populasi tertutup yang terisolasi (Praharani dan Sianturi, 2018). Dampak ekonomi akibat pengaruh tekanan inbreeding adalah penurunan sifat-sifat yang memiliki nilai ekonomi tinggi (Praharani dan Sianturi, 2018). Ternak-ternak muda yang tidak terpilih sebagai breeding stock harus dilakukan kastrasi sehingga kasus inbreeding dapat diminimalisir (Botes, dkk., 2007).

Metode sterilisasi yang dilakukan pada hewan adalah kastrasi untuk hewan jantan dan ovariohisterektomi untuk hewan betina. Kastrasi dengan metode non bedah lebih diminati daripada kastrasi dengan prosedur bedah (Moldave dan Rhodes, 2013). Pendekatan kastrasi non bedah lebih banyak dilakukan di Eropa (Murray, dkk., 2015). Kastrasi dengan prosedur bedah memiliki beberapa komplikasi antara lain inflamasi pada skrotum, hemorrhagi, dan infeksi. Hemorrhagi pasca kastrasi dapat berakibat serius dan dapat menyebabkan hematoma skrotum atau perdarahan intra-abdominal (Howe, 2006). Metode kastrasi menggunakan bahan kimia sebagai alternatif lebih baik daripada kastrasi menggunakan metode bedah (Ibrahim, dkk., 2016). Neto, dkk. (2014) telah menggunakan $\mathrm{NaCl}$ hipertonik 20\% sebagai agen kastrasi kimia pada sapi. Agen $\mathrm{NaCl} 20 \%$ berhasil menyebabkan nekrosis pada sel-sel leydig, tubuli seminiferi, dan testikular sehingga sediaan tersebut dapat digunakan sebagai alternatif dari kastrasi menggunakan metode bedah pada sapi. Ibrahim, dkk. (2016) telah melakukan kastrasi kimia terhadap keledai menggunakan sediaan kalsium klorida 20\%. Sediaan kalsium klorida $20 \%$ tidak dapat menekan kadar testosteron setelah 60 hari injeksi. Ulum, dkk. (2017) melakukan kastrasi kimiawi pada mencit menggunakan $\mathrm{FeCl}_{3} 5 \%$ dan agen tersebut menyebabkan penurunan ukuran testis. Kastrasi kimia yang ideal adalah mampu menekan spermatogenesis dan hormon androgen yang mempengaruhi libido tanpa ada efek samping (Ibrahim, dkk., 2016).

Disinfektan adalah suatu zat yang digunakan untuk mencegah infeksi dengan menghancurkan mikroorganisme patogen (Munaf, 2009). Jenisjenis disinfektan yang pernah digunakan sebagai sediaan kastrasi kimia adalah klorheksidin glikonat pada rusa (Mohamed dan James, 2013), etanol dan kalsium klorida pada banteng (Canpolat, dkk., 2006), dan formalin pada kambing benggala (Awal, dkk., 2004). Bahanbahan kimia lainnya yang terdapat dalam disinfektan antara lain kloroxylenol (McDonnell dan Russell, 1999), iodin (Purnawijayanti, 2001), dan sodium hipoklorit (Utami, dkk., 2016). Iodin dan sodium hipoklorit $(\mathrm{NaOCl})$ bersifat korosif (Queiros, dkk., 2014), sedangkan kloroxylenol dapat menyebabkan iritasi kulit ringan dan memicu terjadinya alergi terhadap beberapa individu (Brahma, dkk., 2016). Bahan-bahan aktif disinfektan tersebut bersifat korosif yang dapat merusak sel dan jaringan sehingga mungkin dapat digunakan sebagai bahan alternatif dalam tindakan kastrasi kimiawi. Penelitian ini bertujuan untuk menguji potensi disinfektan sebagai sediaan bahan kimia untuk kastrasi kimiawi pada mencit sebagai model untuk hewan ternak.

\section{Materi dan Metode}

Penelitian ini dilaksanakan pada bulan Desember 2018 sampai Maret 2019 di Laboratorium Bedah Reproduksi, Divisi 
Reproduksi dan Kebidanan, Departemen Klinik, Reproduksi, dan Patologi, Fakultas Kedokteran Hewan, Institut Pertanian Bogor.

Alat-alat yang digunakan adalah jas lab, gloves, masker, litter box, botol minum mencit, kain, sonde lambung, syringe $1 \mathrm{~mL}$, alat bedah minor, tabung Eppendorf, mikrokapiler, coolbox, alat USG SonoDop S-9X (PT Karindo Alkestron, Indonesia), spon cuci piring, pinset, pot plastik, dan laptop. Bahan-bahan yang digunakan adalah pakan mencit, serutan kayu, obat cacing (Drontal $\left.{ }^{\circledR}\right)$, antibiotik (Claneksi $\left.{ }^{\circledR}\right)$, antiprotozoa (Metrolet $\left.{ }^{\circledR}\right)$, akudestilata, Dettol ${ }^{\circledR}$ (kloroxylenol 4,8\%), Betadine ${ }^{\circledR}$ (povidon iodin $10 \%$ ), Bayclin ${ }^{\circledR}$ (sodium hipoklorit 5,25\%), $\mathrm{NaCl}$ $0,9 \%$, ketamin, larutan BNF 10\%, label, dan air.

Penelitian ini menggunakan 27 ekor mencit jantan berumur 7 bulan dengan bobot badan \pm 42 $\mathrm{g}(\mathrm{n}=16)$ dan 2 bulan bobot badan $\pm 28 \mathrm{~g}(\mathrm{n}=11)$ yang dilakukan dalam 2 tahap setelah aklimatisasi. Proses aklimatisasi pada mencit dilakukan selama 10 hari dan selama proses aklimatisasi mencit diberi obat cacing, antibiotik, dan antiprotozoa. Mencit pada penelitian tahap Idibagi menjadi 4 kelompok perlakuan yaitu: kloroxylenol 4,8\% $(\mathrm{C} 4, \mathrm{n}=4)$, povidon iodin $10 \%$ $(\mathrm{P} 10, \mathrm{n}=4)$, kloroxylenol $2,4 \%$ dan povidon iodin $5 \%(\mathrm{C} 2 \mathrm{P} 5, \mathrm{n}=4)$, dan kloroxylenol 1,2\% dan povidon iodin $2,5 \%(\mathrm{C} 1 \mathrm{P} 2, \mathrm{n}=4)$. Mencit pada penelitian tahap II dibagi dalam 3 kelompok perlakuan yaitu: sodium hipoklorit $(\mathrm{S} 5, \mathrm{n}=4)$, kontrol negatif $\mathrm{NaCl} 0,9 \%$ (kontrol $\mathrm{N}, \mathrm{n}=4$ ), dan kontrol positif akuadestilata (kontrol $\mathrm{A}, \mathrm{n}=3$ ). Penelitian tahap II menggunakan mencit umur 2 bulan karena stok mencit dengan umur 7 bulan tidak ada sehingga yang akan dibandingkaan adalah ukuran relatif dari testis mencit. Ukuran relatif testis dapat dihitung dengan membandingan ukuran organ dan berat badan.

Teknik injeksi kastrasi kimia pada dilakukan dengan mengekang mencit menggunakan kain terlebih dahulu. Testis difiksasi menggunakan jari agar testis turun dari rongga abdomen sehingga mudah dilakukan injeksi intratestikular dalam skrotum (Gambar 1A). Kastrasi kimiawi dilakukan menggunakan syringe $1 \mathrm{~mL}$ dengan needle 27 gauge. Preparat kastrasi kimiawi kemudian diinjeksikan melalui intra-testikular sebanyak $0,2 \mathrm{~mL}$ pada masing-masing testis dengan kedalaman tusukan $\pm 5 \mathrm{~mm}$ (Ulum, dkk., 2017).
Daya hidup mencit dihitung dari pengamatan yang dilakukan setiap hari selama penelitian berlangsung hingga hari ke-7 setelah kastrasi kimiawi. Perhitungan daya hidup dilakukan dengan menghitung jumlah mencit yang hidup setelah perlakuan dibagi jumlah mencit awal sebelum perlakuan dikali $100 \%$ (Ulum, dkk., 2017).

Pemeriksaan profil darah dilakukan dengan mengekang mencit menggunakan kain kemudian dibius menggunakan ketamin $5 \mathrm{mg} / 100 \mathrm{~g} \mathrm{BB}$. Setelah mencit terbius, koleksi sampel darah dilakukan melalui vena orbitalis pada orbita mata. Koleksi sampel darah sebanyak $0,5 \mathrm{~mL}$ dilakukan menggunakan tabung mikrokapiler. Darah ditampung ke dalam tabung Eppendorf yang telah diberi EDTA sebanyak $0,2 \mu \mathrm{L}$. Tabung Eppendorf disimpan ke dalam coolbox dan dilakukan pemeriksaan darah yang meliputi hemoglobin, hematokrit, total eritrosit, total leukosit, dan differensiasi leukosit.

Kastrasi terbuka dilakukan untuk menilai perubahan secara langsung pada testikel setelah kastrasi kimia. Alat bedah minor dipersiapkan sebelum dilakukan kastrasi terbuka. Kastrasi terbuka dilakukan pada hari ke-7 setelah injeksi kastrasi kimia. Mencit jantan terlebih dahulu dibius menggunakan sediaan ketamin $5 \mathrm{mg} / 100 \mathrm{~g}$ BB. Mencit kemudian dieuthanasia dengan cara cervical dislocation. Kulit, tunika vaginalis, dan tunika albuginea disayat menggunakan scalpel. Testis dikeluarkan dari lapisan pembungkusnya serta dipisahkan dari vas deferens dan pembuluh darah. Testis yang telah diangkat disimpan ke dalam pot plastik yang telah diberi BNF $10 \%$ dan diberi label (Destri, 2013).

Pengukuran bobot testistkel yang sudah diawetkan dalam BNF $10 \%$ dilakukan menggunakan timbangan digital. Dimensi testis diukur pada panjang dan lebar menggunakan jangka sorong. Pengukuran volume testis dilakukan menggunakan rumus volume testis (Sakamoto, dkk., 2007). Ukuran testis mencit yang akan dibandingkan diantara kelompok adalah ukuran relatif. Ukuran relatif didapat dengan membagi ukuran aktual dengan BB masing-masing mencit.

Citra ultrasonografi diambil untuk menilai struktur bagian dalam dari testikel setelah kastrasi kimiawi. Perangkat alat ultrasonografi SonoDop S-9X dipersiapkan kemudian transduser diatur 
pada frekuensi $10 \mathrm{MHz}$. Awetan organ testis diambil menggunakan pinset dari pot plastik yang berisi larutan BNF 10\%. Proses pencitraan organ dilakukan di dalam air sebagai media penghantar. Arah transduser terhadap organ adalah transversal dan longitudinal. Hasil gambar sonogram kemudian disimpan ke dalam flash disk untuk dianalisa lebih lanjut (NIH, USA).

Pemeriksaan patologi anatomi dilakukan dengan membuka testikel yang telah diawetkan dalam BNF 10\%. Testis dipotong menggunakan pisau mikrotom menjadi empat bagian dengan arah pemotongan transversal untuk membandingkan kerusakan yang terlihat secara makroanatomi. Testis yang telah dipotong kemudian diwarnai menggunakan eosin giemsa dan diambil gambar menggunakan mikroskop stereo yang telah dilengkapi dengan kamera digital. Gambar jaringan secara plain (tanpa pewarna) kemudian dibandingkan dengan gambar dari jaringan yang telahdiwarnai dengan eosin giemsa.

Data yang diperoleh dianalisis secara kuantitatif dan kualitatif. Pengujian data daya hidup dianalisis menggunakan WPS Spreadsheets 2010 dengan metode deskriptif. Data hasil hemogram dan ukuran testis dianalisis secara statistik menggunakan perangkat lunak SPSS ${ }^{\circledR}$ v.16 dengan uji lanjut Duncan pada selang kepercayaan 95\% $(\mathrm{p}<0,05)$. Data hasil citra USG dan pewarnaan jaringan dianalisis secara deskriptif.

\section{Hasil dan Pembahasan}

Penelitian ini telah berhasil menguji potensi berbagai bahan disinfektan sebagai zat aktif kastrasi kimiawi pada mencit. Kastrasi kimiawi mudah dilakukan tanpa perlu melakukan kastrasi terbuka. Kastrasi kimia dilakukan dengan cara injeksi senyawa secara intra-testikular (ITI) dapat menginduksi kerusakan sel testis melalui proses kaustik atau osmotik (Oliveira, dkk., 2016).

Tabel 1 menunjukkan kelompok perlakuan P10 dan S5 mengalami kematian semua populasi mencit dalam waktu 24 jam setelah injeksi. Mencit pada kelompok perlakuan C4, C2P5, $\mathrm{C} 1 \mathrm{P} 2, \mathrm{~A}$, dan $\mathrm{N}$ memiliki daya hidup hingga hari ke-7 setelah injeksi. Daya hidup 100\% ditunjukkan oleh mencit pada kelompok perlakuan N, A, dan C1P2. Daya hidup 25\% ditunjukkan oleh mencit pada kelompok $\mathrm{C} 4$ dan C2P5.

Konsentrasi povidon iodin 10\% (P10) dan sodium hipoklorit 5,25\% (S5) yang diberikan dengan rute intra-testikular bersifat toksik. Mencit pada kelompok tersebut semuanya mengalami kematian dalam 24 jam. Mencit menunjukkan reaksi hiperaktif pada kelompok P10 dan S5 setelah injeksi intra-testikular senyawa disinfektan. Senyawa aktif yang digunakan untuk kastrasi kimiawi dapat terdistribusikan secara sistemik melalui pembuluh darah mencit (Ulum, dkk., 2017). Sodium hipoklorit merupakan disinfektan tingkat tinggi yang toksisitasnya dipengaruhi oleh komposisi kimia, konsentrasi, dan volume pemberian (Mehdipour, dkk.,2007). Sodium hipoklorit sangat beracun pada jaringan vital dan saraf. Sodium hipoklorit apabila berkontak dengan jaringan vital dapat menyebabkan hemolisis, ulserasi, penghambatan reaksi neutrofil, dan penghancuran sel endotel serta fibroblast (Guivarc, dkk., 2017). Povidon iodin pada jaringan vital juga dapat menyebabkan edema dan kerusakan sel endotel (Liesegang, 2002).

Tabel 1. Daya hidup mencit setelah dilakukan kastrasi kimiawi menggunakan sediaan disinfektan selama 7 hari

\begin{tabular}{|c|c|c|c|c|c|c|c|c|c|c|}
\hline \multirow{2}{*}{$\begin{array}{l}\text { Tahap } \\
\text { Penelitian }\end{array}$} & \multirow{2}{*}{$\begin{array}{l}\text { Kelompok } \\
\text { Perlakuan }\end{array}$} & \multirow[b]{2}{*}{$\mathbf{n}$} & \multicolumn{8}{|c|}{ Daya Hidup (\%) hari ke- } \\
\hline & & & $\mathbf{0}$ & 1 & 2 & 3 & 4 & 5 & 6 & 7 \\
\hline \multirow[t]{4}{*}{$\mathrm{I}$} & $\mathrm{C} 4$ & 4 & 100 & 25 & 25 & 25 & 25 & 25 & 25 & 25 \\
\hline & P10 & 4 & 100 & 0 & 0 & 0 & 0 & 0 & 0 & 0 \\
\hline & $\mathrm{C} 2 \mathrm{P} 5$ & 4 & 100 & 25 & 25 & 25 & 25 & 25 & 25 & 25 \\
\hline & $\mathrm{C} 1 \mathrm{P} 2$ & 4 & 100 & 100 & 100 & 100 & 100 & 100 & 100 & 100 \\
\hline \multirow[t]{3}{*}{ II } & A (kontrol) & 3 & 100 & 100 & 100 & 100 & 100 & 100 & 100 & 100 \\
\hline & $\mathrm{N}$ (kontrol) & 4 & 100 & 100 & 100 & 100 & 100 & 100 & 100 & 100 \\
\hline & S5 & 4 & 100 & 0 & 0 & 0 & 0 & 0 & 0 & 0 \\
\hline
\end{tabular}

Keterangan: $\mathrm{A}=$ akuadestilata, $\mathrm{N}=\mathrm{NaCl} 0,9 \%, \mathrm{C} 4=$ kloroxylenol $4,8 \%, \mathrm{P} 10=$ povidon iodin $10 \%, \mathrm{C} 2 \mathrm{P} 5=$ kloroxylenol $2,4 \%$ dan povidon iodin $5 \%, \mathrm{C} 1 \mathrm{P} 2=$ kloroxylenol $1,2 \%$ dan povidon iodin $2,5 \%, \mathrm{~S} 5=$ sodium hipoklorit $5,25 \%$. 
Hemogram merupakan nilai komponenkomponen darah yang dapat digunakan untuk mengetahui kondisi kesehatan tubuh. Menurut Opara, dkk. (2010) dan Jasper, dkk. (2012), nilai komponen-komponen darah dapat digunakan sebagai indikator uji toksisitas suatu bahan terutama yang mempengaruhi darah serta status kesehatan hewan. Tabel 2 menunjukkan hasil pemeriksaan hemogram mencit setelah hari ke-7 kastrasi kimiawi menggunakan disinfektan. Jumlah eritrosit, limfosit relatif, dan neutrofil relatif menunjukkan hasil yang berbeda nyata diantara kelompok $(\mathrm{P}<0,05)$ setelah dilakukan kastrasi kimiawi. Kelompok kontrol N memiliki nilai total eritrosit sedikit di bawah rentang nilai normal $\left(5,0-9,5 \times 10^{6} / \mu 1\right)$. Kelompok perlakuan $\mathrm{C} 4, \mathrm{C} 2 \mathrm{P} 5$, dan C1P2 memiliki jumlah eritrosit sedikit berada di atas nilai normal $(5,0-9,5 \mathrm{x}$ $\left.10^{6} / \mu \mathrm{l}\right)$. Jumlah limfosit relatif pada semua kelompok perlakuan dan berada dalam rentang nilai normal (36 - 90\%). Kelompok perlakuan N, $\mathrm{A}$, dan C2P5 memiliki jumlah neutrofil relatif berada di atas rentang nilai normal (6 - 40\%). Kelompok perlakuan C4 dan C1P2 memiliki jumlah neutrofil relatif berada pada rentang nilai normal (6 - 40\%).

Tabel 2. Profil hemogram mencit pada hari ke-7 setelah dilakukan kastrasi kimiawi menggunakan disinfektan.

\begin{tabular}{|c|c|c|c|c|c|c|c|}
\hline \multirow{3}{*}{ Parameter } & \multirow{3}{*}{$\begin{array}{l}\text { Nilai } \\
\text { Normal }\end{array}$} & \multicolumn{5}{|c|}{ Kelompok Perlakuan } & \multirow{3}{*}{$\begin{array}{c}\text { Nilai } \\
\mathbf{P}\end{array}$} \\
\hline & & \multicolumn{3}{|c|}{ Tahap I } & \multicolumn{2}{|l|}{ Tahap II } & \\
\hline & & $\mathrm{C4}$ & C2P5 & C1P2 & $\mathbf{N}$ & $\mathbf{A}$ & \\
\hline Hemoglobin (g/dL) & $10-17 * * *$ & $11,60 \pm 0,00^{\mathrm{a}}$ & $11,20 \pm 0,00^{\mathrm{a}}$ & $14,45 \pm 1,30^{a}$ & $\begin{array}{l}14,00 \pm 2,10 \\
\text { a }\end{array}$ & $13,73 \pm 2,30^{\mathrm{a}}$ & 0,498 \\
\hline Hematokrit (\%) & $39-49 * * *$ & $43,50 \pm 0,00^{\mathrm{a}}$ & $41,50 \pm 0,00^{\mathrm{a}}$ & $38,98 \pm 3,70^{\mathrm{a}}$ & $\begin{array}{l}41,75 \pm 5,97 \\
\mathrm{a}\end{array}$ & $44,92 \pm 2,01^{\mathrm{a}}$ & 0,547 \\
\hline Eritrosit (x 106/ $\mu \mathrm{l})$ & $5,0-9,5 * * *$ & $11,56 \pm 0,00^{\mathrm{a}}$ & $10,56 \pm 0,00^{\mathrm{a}}$ & $10,34 \pm 1,50^{\mathrm{a}}$ & $4,60 \pm 0,66^{b}$ & $6,20 \pm 2,17^{\mathrm{ab}}$ & 0,003 \\
\hline 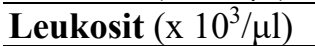 & $5-12 * * *$ & $8,30 \pm 0,00^{\mathrm{a}}$ & $7,55 \pm 0,00^{\mathrm{a}}$ & $3,80 \pm 1,20^{\mathrm{a}}$ & $7,50 \pm 2,34^{\mathrm{a}}$ & $8,33 \pm 3,59^{a}$ & 0,181 \\
\hline \multicolumn{8}{|l|}{ Limfosit } \\
\hline Relatif (\%) & $36-90 * *$ & $\underset{\mathrm{b}}{57,00 \pm 0,00^{\mathrm{a}}}$ & $\begin{array}{l}43,00 \pm 0,00^{\mathrm{a}} \\
\mathrm{b}\end{array}$ & $73,00 \pm 14,10$ & $\begin{array}{l}41,67 \pm 4,16 \\
\mathrm{~b}\end{array}$ & $37,50 \pm 9,75^{\mathrm{b}}$ & 0,012 \\
\hline 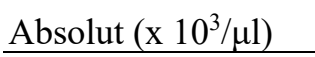 & $3,22-11,20 *$ & $4,73 \pm 0,00^{\mathrm{a}}$ & $3,25 \pm 0,00^{\mathrm{a}}$ & $2,75 \pm 0,90^{\mathrm{a}}$ & $2,77 \pm 1,10^{\mathrm{a}}$ & $3,52 \pm 1,76^{\mathrm{a}}$ & 0,631 \\
\hline \multicolumn{8}{|l|}{ Neutrofil } \\
\hline Relatif (\%) & $6-40 * *$ & $\begin{array}{l}38,00 \pm 0,00^{\mathrm{a}} \\
\mathrm{b}\end{array}$ & ${ }_{\mathrm{b}}^{54,00 \pm 0,00^{\mathrm{a}}}$ & $\begin{array}{l}24,50 \pm 13,70 \\
\mathrm{~b}\end{array}$ & $\begin{array}{l}51,67 \pm 2,52 \\
\text { a }\end{array}$ & $\begin{array}{l}57,00 \pm 9,59^{a} \\
b\end{array}$ & 0,017 \\
\hline Absolut $\left(\times 10^{3} / \mu 1\right)$ & $0,46-2,20 *$ & $3,15 \pm 0,00^{\mathrm{a}}$ & $4,08 \pm 0,00^{\mathrm{a}}$ & $0,95 \pm 0,75^{\mathrm{a}}$ & $4,33 \pm 1,72^{\mathrm{a}}$ & $4,26 \pm 1,65^{\mathrm{a}}$ & 0,055 \\
\hline \multicolumn{8}{|l|}{ Monosit } \\
\hline Relatif (\%) & $0,7-14 * *$ & $2,00 \pm 0,00^{\mathrm{a}}$ & $2,00 \pm 0,00^{\mathrm{a}}$ & $2,25 \pm 1,30^{\mathrm{a}}$ & $4,00 \pm 1,73^{\mathrm{a}}$ & $3,00 \pm 0,82^{\mathrm{a}}$ & 0,424 \\
\hline Absolut $\left(\mathrm{x} 10^{3} / \mu \mathrm{l}\right)$ & $0,40-1,43^{*}$ & $0,17 \pm 0,00^{\mathrm{a}}$ & $0,15 \pm 0,00^{\mathrm{a}}$ & $0,08 \pm 0,04^{\mathrm{a}}$ & $0,24 \pm 0,12^{\mathrm{a}}$ & $0,32 \pm 0,15^{\mathrm{a}}$ & 0,136 \\
\hline \multicolumn{8}{|l|}{ Eosinofil } \\
\hline Relatif (\%) & $0-15 * *$ & $3,00 \pm 0,00^{\mathrm{a}}$ & $1,00 \pm 0,00^{\mathrm{a}}$ & $0,25 \pm 0,50^{\mathrm{a}}$ & $1,67 \pm 1,15^{\mathrm{a}}$ & $0,75 \pm 0,50^{\mathrm{a}}$ & 0,052 \\
\hline Absolut (x $\left.10^{3} / \mu \mathrm{l}\right)$ & $0-0,38 *$ & $0,25 \pm 0,00^{\mathrm{a}}$ & $0,08 \pm 0,00^{\mathrm{a}}$ & $0,01 \pm 0,03^{\mathrm{a}}$ & $0,60 \pm 0,40^{\mathrm{a}}$ & $0,17 \pm 0,18^{\mathrm{a}}$ & 0,202 \\
\hline \multicolumn{8}{|l|}{ Basofil } \\
\hline Relatif $(\%)$ & $0-3 * *$ & $0,00 \pm 0,00^{\mathrm{a}}$ & $0,00 \pm 0,00^{\mathrm{a}}$ & $0,00 \pm 0,00^{\mathrm{a}}$ & $0,00 \pm 0,00^{\mathrm{a}}$ & $0,00 \pm 0,00^{\mathrm{a}}$ & n.a. \\
\hline Absolut (x 103/ $\mu \mathrm{l})$ & $0-0,09 *$ & $0,00 \pm 0,00^{\mathrm{a}}$ & $0,00 \pm 0,00^{\mathrm{a}}$ & $0,00 \pm 0,00^{\mathrm{a}}$ & $0,00 \pm 0,00^{\mathrm{a}}$ & $0,00 \pm 0,00^{\mathrm{a}}$ & \\
\hline \multicolumn{8}{|l|}{ Rasio N/L } \\
\hline Relatif & $0,17-0,44^{* *}$ & $0,67 \pm 0,00$ & $1,26 \pm 0,00$ & $0,31 \pm 0,13$ & $1,25 \pm 0,06$ & $1,56 \pm 0,15$ & n.a. \\
\hline Absolut & $0,14-0,20^{*}$ & $0,67 \pm 0,00$ & $1,26 \pm 0,00$ & $0,29 \pm 0,18$ & $1,56 \pm 0,00$ & $1,30 \pm 0,18$ & n.a. \\
\hline $\begin{array}{r}\text { Keterangan: } \\
\text { pata di } \\
\text { klorox } \\
\text { poviod } \\
\text { Pramo }\end{array}$ & kan dalam ben & $\begin{array}{l}\text { ituk rataan den } \\
\text { henunjukkan b } \\
5=\text { kloroxyle }\end{array}$ & $\begin{array}{l}\text { ngan standar } \\
\text { oerbeda nyata } \\
\text { enol } 2,4 \% \text { da } \\
\text { lak tersedia. } \\
17 \text { ). }\end{array}$ & $\begin{array}{l}\text { deviasi }(\mathrm{x} \pm \mathrm{S} \\
(\mathrm{P}<0,05) . \mathrm{A} \\
\text { in povidon io } \\
\text { Sumber: }{ }^{*}(\mathrm{~S}\end{array}$ & $\begin{array}{l}\text { Huruf (supers } \\
\text { dadestilata, } \\
5 \%, \mathrm{C} 1 \mathrm{P} 2= \\
\text { W, dkk., } 200\end{array}$ & $\begin{array}{l}\text { script) yang be } \\
\mathrm{J}=\mathrm{NaCl} 0,9 \% \\
\text { kloroxylenol } \\
01), * *(\text { Malol }\end{array}$ & $\begin{array}{l}\text { erbeda } \\
0, \mathrm{C} 4= \\
1,2 \% \\
\text { le dan }\end{array}$ \\
\hline
\end{tabular}


Hemoglobin merupakan substansi utama penyusun eritrosit yang terdiri dari protein (globin) dan bagian non-protein (heme). Hemoglobin dapat dijadikan parameter untuk mengetahui terjadinya anemia (Widyastuti, 2013). Jumlah hemoglobin, hematokrit, dan leukosit mencit setelah 7 hari kastrasi kimiawi diantara semua kelompok tidak berbeda nyata $(\mathrm{P}>0,05)$. Hal tersebut menunjukkan bahwa kastrasi kimiawi tidak mempengaruhi respon hemoglobin, hematokrit, dan leukosit pada mencit. Hematokrit merupakan presentase eritrosit di dalam $100 \mathrm{~mL}$ darah (Astawan, dkk., 2011). Kastrasi kimiawi mempengaruhi respon eritrosit pada mencit. Jumlah eritrosit mencit setelah 7 hari kastrasi kimiawi diantara kelompok menunjukkan adanya perbedaan yang nyata $(\mathrm{P}<0,05)$. Jumlah eritrosit mencit pascakastrasi kimiawi berada di atas rentang nilai normal. Menurut Marquardt, dkk. (2010), povidon iodin dan kloroxylenol yang diinokulasi pada telur berembrio menyebabkan hemoragi pada pembuluh darah. Peningkatan nilai eritrosit dapat terjadi karena respon dari sumsum tulang untuk memproduksi eritrosit agar nilai eritrosit kembali normal (Weiss dan Wardrop, 2010). Proses inflamasi menyebabkan vasodilatasi pembuluh darah kemudian meningkatkan sirkulasi darah ke daerah luka dan sekitarnya untuk mensuplai nutrisi bagi sel (Abdurrahmat, 2014). Peningkatan nilai eritrosit kelompok perlakuan C4, C2P5, dan C1P2 lebih tinggi dari kedua kontrol dan berada di atas nilai normal. Peningkatan jumlah eritrosit di atas nilai normal di dalam tubuh dapat menyebabkan polisitemia (Weiss dan Wardrop, 2010).

Leukosit di dalam tubuh berperan sebagai sistem pertahanan terhadap benda asing (Colville dan Bassert, 2008). Limfosit $\mathrm{T}$ berperan dalam respon kekebalan seluler melalui pembentukan sel yang reaktif antigen. Limfosit B berperan dalam kekebalan humoral (D'Hiru, 2013). Akan tetapi, jumlah limfosit relatif setelah 7 hari kastrasi kimiawi menunjukkan berbeda nyata ( $\mathrm{P}$ $=0,012)$. Jumlah limfosit relatif pada semua kelompok perlakuan berada dalam rentang nilai normal (36 - 90\%), akan tetapi apabila dibandingkan dengan kelompok kontrol jumlah limfosit kelompok C4, C2P5, dan C1P2 terjadi peningkatan. Limfosit merupakan sel pertahanan tubuh yang berperan pada proses inflamasi setelah neutrofil (Izzaty, dkk., 2014).

Neutrofil merupakan garis pertahanan pertama terhadap invasi mikroorganisme, trauma pada jaringan, dan peradangan (Weiss dan Wardrop, 2010). Kastrasi kimiawi mempengaruhi respon neutrofil pada mencit. Nilai neutrofil relatif pada kelompok perlakuan C2P5 berada di atas rentang nilai normal yang disebabkan oleh proses inflamasi setelah injeksi intra-testikular senyawa disinfektan. Hal tersebut sesuai dengan Guyton dan Hall (2016) yang menyatakan bahwa proses inflamasi menyebabkan infiltrasi neutrofil meningkat atau terjadi neutrofilia karena neutrofil merupakan pertahanan awal terhadap infeksi atau inflamasi. Jumlah neutrofil relatif pada kelompok $\mathrm{N}$ dan A berada di atas rentang nilai normal dibandingkan dengan literatur. Menurut Restel, dkk. (2014), hewan yang masih muda memiliki jumlah neutrofil lebih tinggi dibandingkan dengan hewan yang umurnya lebih tua. Faktor faktor yang mempengaruhi hasil hematologi adalah umur, jenis kelamin, makanan, kondisi lingkungan, kondisi puasa, cara pengambilan sampel, antikoagulan, penanganan hewan sebelum pengambilan sampel, dan analisis (Weiss dan Wardrop, 2010).

Ratio neutrofil limfosit (N/L) didapatkan dari perhitungan jumlah neutrofil dibagi dengan jumlah limfosit. Ratio N/L dapat digunakan sebagai indikator stress yang terjadi pada hewan (Kannan, dkk., 2000). Ratio N/L mencit pada kelompok perlakuan (C4, C1P2, dan C2P5) dan kontrol ( $\mathrm{N}$ dan $\mathrm{A})$ setelah 7 hari kastrasi kimiawi cenderung lebih tinggi dari rentang nilai normal rasio relatif $\mathrm{N} / \mathrm{L}$ referensi $0,17-0,44$ (Suckow, dkk., 2001) maupun rasio N/L absolut 0,14-0,20 (Malole dan Pramono, 1989). Hewan mamalia seperti kambing dapat dikatakan stress apabila mempunyai nilai ratio $\mathrm{N} / \mathrm{L}<1,5$ (Kannan, dkk., 2000). Mencit setelah kastrasi kimiawi dalam penelitian ini tidak mengalami stress seluler pada semua kelompok perlakuan $(\mathrm{C} 4, \mathrm{C} 1 \mathrm{P} 2$, dan $\mathrm{C} 2 \mathrm{P} 5)$ maupun kelompok kontrol (N dan A).

Monosit merupakan bagian dari sel darah putih yang dapat berdiferensiasi menjadi makrofag dan sel dendritik (Auffray, dkk., 2009). Jumlah monosit mencit dalam penelitian ini tidak dipengaruhi oleh kastrasi kimiawi. Eosinofil di dalam tubuh berperan untuk melawan parasit. 
Eosinofil bersamaan dengan basofil atau sel mast berperan sebagai mediator peradangan serta berpotensi merusak jaringan (Behm dan Ovington, 2000). Basofil merupakan komponen leukosit yang berperan dalam reaksi terhadap alergi (Merck, 2007). Kastrasi kimiawi tidak mempengaruhi respon monosit, eosinofil, dan basofil pada mencit.

Tabel 3 menunjukkan profil biologi testis mencit setelah 7 hari kastrasi kimiawi menggunakan disinfektan. Perlakuan kastrasi kimiawi menggunakan disinfektan memberikan pengaruh nyata $(\mathrm{P}=0,004)$ pada panjang relatif testis. Panjang relatif testis paling kecil tampak pada kelompok perlakuan C4. Kelompok perlakuan $\mathrm{C} 4$ memiliki penurunan ukuran testis yang lebih besar dibandingkan dengan kelompok perlakuan C1P2 dan C2P5. Hal tersebut menunjukkan bahwa konsentrasi dan jenis disinfektan berpengaruh terhadap proses kerusakan jaringan testis. Kelompok perlakuan desinfektan tunggal (C4) menyebabkan kerusakan jaringan testis yang lebih besar dibandingkan kelompok perlakuan desinfektan kombinasi (C1P2 dan C2P5). Kerusakan jaringan tersebut ditandai dengan penurunan ukuran testis.

Bobot relatif testis, lebar relatif testis, dan volume relatif testis mengalami penurunan pada kelompok perlakuan (C4, C2P5, dan C1P2) dibandingkan dengan kedua kontrol ( $\mathrm{N}$ dan $\mathrm{A})$ tetapi tidak berbeda nyata $(\mathrm{P}>0,05)$. Ukuran testis pada semua kelompok perlakuan setelah hari ke7 kastrasi kimiawi menggunakan sediaan disinfektan mengalami penurunan ukuran. Kelompok perlakuan $\mathrm{C} 4$ dan C2P5 memiliki penurunan ukuran testis paling besar dibandingkan dengan kedua kontrol. Kelompok perlakuan $\mathrm{C} 1 \mathrm{P} 2$ penurunan ukuran testis paling kecil dibandingkan dengan kedua kontrol. Hal tersebut dipengaruhi oleh jenis dan konsentrasi disinfektan yang diberikan. Konsentrasi tinggi pada disinfektan yang diberikan lebih berpengaruh terhadap penurunan ukuran testis. Meskipun jenis disinfektan kloroksilenol dan povidon iodin dikombinasikan pada konsentrasi kloroksilenol $1,2 \%$ dan povidon iodine 2,5\% (kelompok C1P2) serta kloroksilenol 2,4\% dan povidon iodine $5 \%$ (C2P5), namum dampak kerusakan jaringan lebih besar diakibatkan oleh disinfektan jenis kloroksilenol pada konsentrasi 4,8\% (C4). Kelompok perlakuan C4 memiliki konsentrasi disinfektan yang lebih tinggi dibandingkan dengan kelompok perlakuan C2P5 dan C1P2. Penurunan ukuran testis disebabkan oleh potensi disinfektan yang menyebabkan kerusakan pada jaringan testis. Menurut Marquardt, dkk. (2010), kloroxylenol dan povidon iodin menyebabkan iritasi pada pembuluh darah. Disinfektan dalam testis akan mengiritasi pembuluh darah sehingga terjadi kerusakan dinding pembuluh darah. Kerusakan pembuluh darah sekitar testis menyebabkan suplai oksigen oleh eritrosit meunuju jaringan testis terganggu sehingga terjadi hipoksia pada jaringan sekitar testis. Hipoksia di sekitar jaringan testis menyebabkan kematian jaringan testis. Disinfektan yang terdeposit di sel-sel pada tubuli seminiferus menyebabkan kerusakan sel sehingga produksi spermatozoa menjadi terhambat atau tidak dapat diproduksi.

Gambar 1 merupakan testis mencit setelah 7 hari kastrasi kimiawi menggunakan disinfektan dibandingkan dengan kontrol. Setelah dilakukan kastrasi kimiawi menggunakan disinfektan testis mengalami kerusakan pada tunika testis dan ukuran menjadi mengecil. Menurut Marquardt, dkk. (2010), kloroxylenol dan povidon iodin yang di inokulasi pada telur berembrio menyebabkan iritasi pada pembuluh darah. Kloroxylenol memiliki skor iritasi sebesar 17,4 (iritasi berat) dan povidon iodin memiliki skor iritasi sebesar 5,3 (iritasi sedang) (Marquardt, dkk., 2010). Injeksi disinfektan intra-testikular menyebabkan inflamasi pada testis. Proses inflamasi yang terjadi terus-menerus akan menyebabkan nekrosa pada testis. Disinfektan yang terdeposit di sel-sel pada tubuli seminiferus menyebabkan kerusakan sel sehingga produksi spermatozoa menjadi terhambat atau tidak dapat diproduksi.

Pengambilan gambar ultrasonografi dilakukan dengan arah transduser longitudinal dan transversal (Gambar 2). Hasil pemeriksaan ultrasonografi menunjukkan bahwa jaringan testis yang telah dikastrasi kimiawi menggunakan disinfektan terjadi penurunan ekogenitas. Garis putus-putus berwarna kuning menunjukkan terjadinya pengumpulan cairan yang ditandai dengan struktur anekhoik. Struktur anekhoik paling besar pada sonogram ditunjukkan oleh kelompok perlakuan C4, sedangkan struktur anekhoik paling kecil ditunjukkan oleh kelompok perlakuan $\mathrm{C} 1 \mathrm{P} 2$. 
Tabel 3. Profil biologis testis mencit pada hari ke - 7 setelah dilakukan kastrasi kimiawi disinfektan.

\begin{tabular}{|c|c|c|c|c|c|c|}
\hline \multirow{3}{*}{ Parameter } & \multicolumn{5}{|c|}{ Kelompok Perlakuan } & \multirow{3}{*}{ Nilai $P$} \\
\hline & \multicolumn{3}{|c|}{ Tahap I } & \multicolumn{2}{|l|}{ Tahap II } & \\
\hline & $\mathrm{C} 4$ & C2P5 & C1P2 & $\mathbf{A}$ & $\mathbf{N}$ & \\
\hline Bobot badan (g) & $39,00 \pm 0,00$ & $42,00 \pm 0,00$ & $43,25 \pm 6,18$ & $33,67 \pm 8,09$ & $26,75 \pm 1,50$ & n.a. \\
\hline \multicolumn{7}{|l|}{ Bobot testis } \\
\hline Absolut (g) & $0,13 \pm 0,00$ & $0,14 \pm 0,00$ & $0,19 \pm 0,05$ & $0,13 \pm 0,01$ & $0,14 \pm 0,03$ & \\
\hline Relatif $(\%)$ & $0,33 \pm 0,00^{\mathrm{a}}$ & $0,32 \pm 0,00^{\mathrm{a}}$ & $0,43 \pm 0,11^{\mathrm{a}}$ & $0,40 \pm 0,06^{\mathrm{a}}$ & $0,51 \pm 0,10^{\mathrm{a}}$ & 0,340 \\
\hline \multicolumn{7}{|l|}{ Panjang testis } \\
\hline Absolut (mm) & $6,25 \pm 0,00$ & $6,83 \pm 0,00$ & $7,27 \pm 0,51$ & $6,84 \pm 0,46$ & $7,23 \pm 0,75$ & \\
\hline Relatif (mm/g) & $16,03 \pm 0,00^{\mathrm{b}}$ & $16,26 \pm 0,00^{\mathrm{b}}$ & $17,09 \pm 2,92^{\mathrm{b}}$ & $20,83 \pm 3,32^{\mathrm{ab}}$ & $26,97 \pm 1,40^{\mathrm{a}}$ & 0,004 \\
\hline \multicolumn{7}{|l|}{ Lebar testis } \\
\hline Absolut (mm) & $3,65 \pm 0,00$ & $4,08 \pm 0,00$ & $4,82 \pm 0,46$ & $4,13 \pm 0,13$ & $3,90 \pm 0,34$ & \\
\hline Relatif (mm/g) & $9,36 \pm 0,00^{\mathrm{a}}$ & $9,71 \pm 0,00^{\mathrm{a}}$ & $11,36 \pm 2,29^{\mathrm{a}}$ & $12,68 \pm 2,70^{\mathrm{a}}$ & $14,60 \pm 1,22^{\mathrm{a}}$ & 0,144 \\
\hline \multicolumn{7}{|l|}{ Volume testis } \\
\hline Absolut $\left(\mathrm{cm}^{3}\right)$ & $74,18 \pm 0,00$ & $89,03 \pm 0,00$ & $126,59 \pm 27,46$ & $89,81 \pm 12,16$ & $88,22 \pm 17,07$ & \\
\hline Relatif $\left(\mathrm{cm}^{3} / \mathrm{g}\right)$ & $1,90 \pm 0,00^{\mathrm{a}}$ & $2,12 \pm 0,00^{\mathrm{a}}$ & $2,99 \pm 0,81^{\mathrm{a}}$ & $2,74 \pm 0,57^{\mathrm{a}}$ & $3,28 \pm 0,49^{\mathrm{a}}$ & 0,323 \\
\hline
\end{tabular}

Keterangan: Data disajikan dalam bentuk rataan dengan standar deviasi (x \pm SD). Huruf (superscript) yang berbeda pada baris yang sama menunjukkan berbeda nyata $(\mathrm{P}<0,05) . \mathrm{A}=$ akuadestilata, $\mathrm{N}=\mathrm{NaCl} 0,9 \%$, $\mathrm{C} 4=$ kloroxylenol 4,8\%, C2P5= kloroxylenol $2,4 \%$ : povidon iodin $5 \%, \mathrm{C} 1 \mathrm{P} 2=$ kloroxylenol 1,2\% : povidon iodin $2,5 \%$ dan $n . a .=$ tidak tersedia.

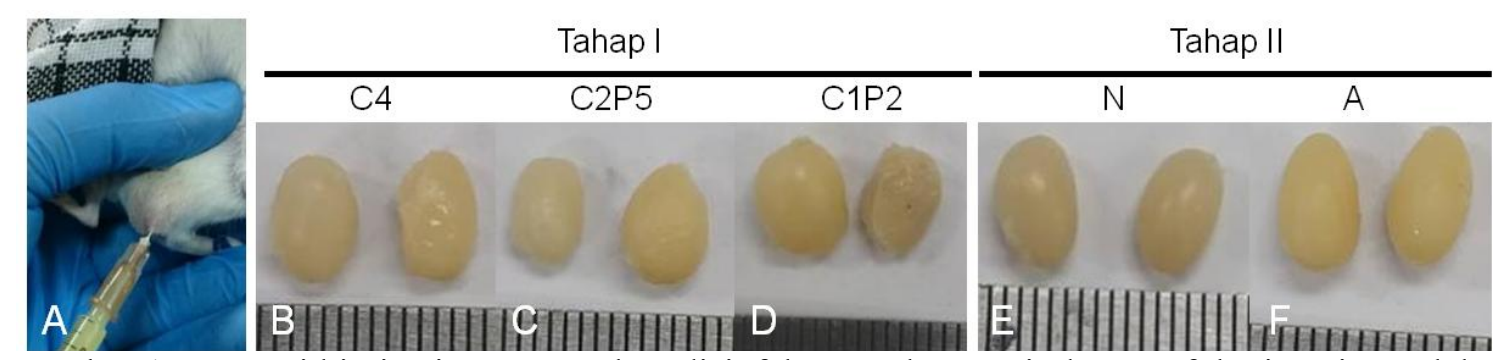

Gambar 1. Kastrasi kimiawi menggunakan disinfektan pada mencit dan morfologi testis setelah tujuh hari pengamatan. (A) prosedur kastrasi kimiawi. (B-F) organ testis pascaskastrasi kimiawi menggunakan (B) kloroxylenol 4,8\%, (C) kloroxylenol 2,4\% dan povidon iodin 5\%, (D) kloroxylenol 1,2\% dan povidon iodin 2,5\%, (E) $\mathrm{NaCl} \mathrm{0,9 \% ,} \mathrm{(F)} \mathrm{akuades.}$ 


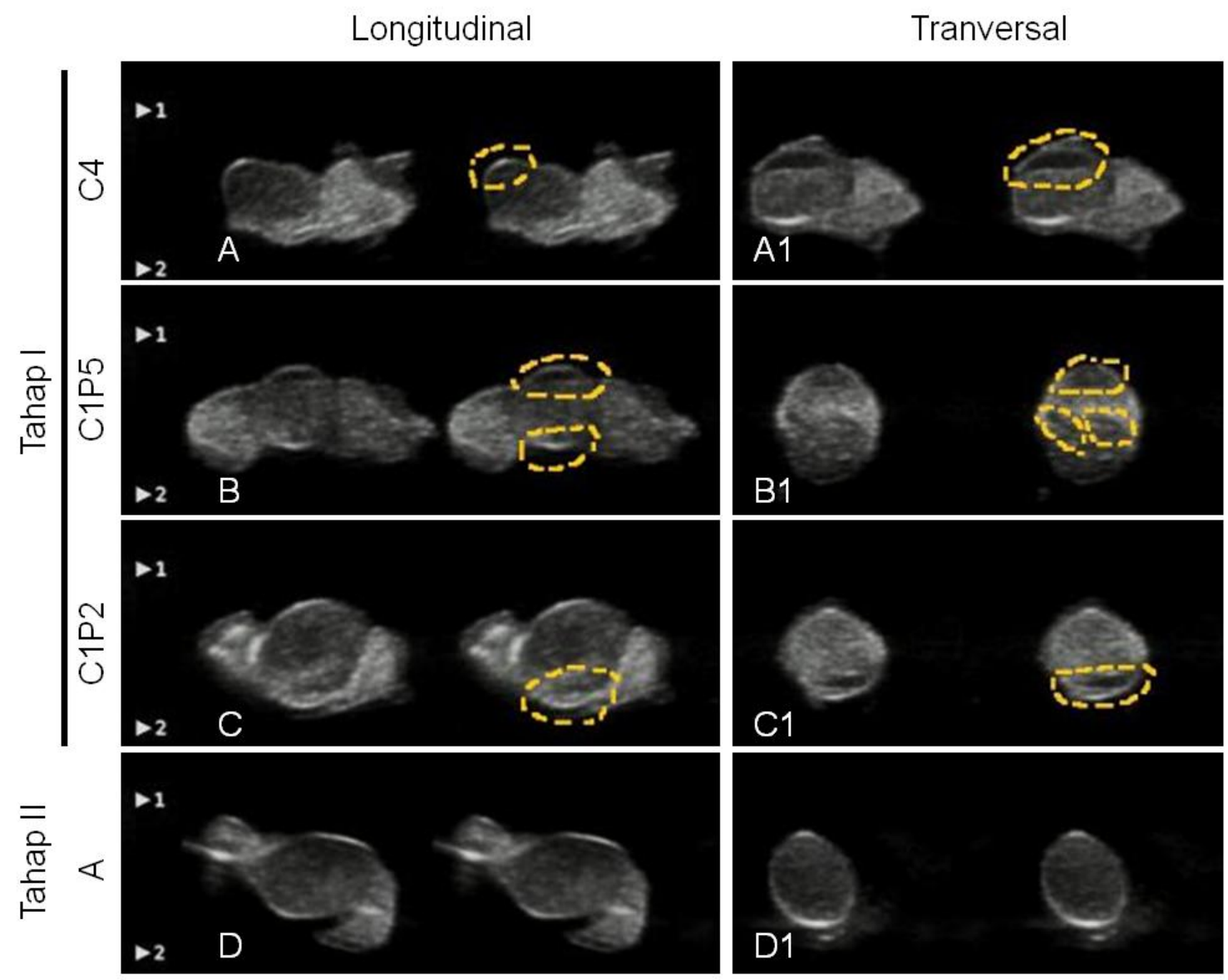

Gambar 2. Tampilan sonogram testis mencit pada hari ke -7 setelah dilakukan kastrasi kimiawi disinfektan. (A) $\mathrm{C} 4=$ kloroxylenol 4,8\%, (B) C2P5= kloroxylenol 2,4\% dan povidon iodin 5\%, (C) $\mathrm{C} 1 \mathrm{P} 2=$ kloroxylenol $1,2 \%$ dan povidon iodin $2,5 \%$, (D) $\mathrm{A}=$ akuadestilata.

Pencitraan ultrasonografi adalah teknik diagnosis yang cukup sensitif pada jaringan lunak (Noviana, dkk., 2012). Hasil pencitraan ultrasonografi terdiri atas tiga bagian yaitu hiperekhoik (putih), hipoekhoik (abu-abu), anekhoik (hitam) (Satria, dkk., 2016). Struktur hiperekhoik pada tampilan sonogram testis mencit merupakan jaringan ikat testis, sedangkan struktur hipoekhoik dicitrakan oleh jaringan lunak. Tampilan sonogram testis mencit setelah dilakukan kastrasi kimiawi menunjukkan struktur anekhoik. Ultrasonografi merupakan alat diagnostik yang berfungsi untuk menampilkan perubahan yang terjadi dalam jaringan lunak termasuk dalam penelitian ini mampu menampilkan struktur jaringan testikel setelah kastrasi kimiawi. Konsentrasi larutan disinfektan yang diinjekasi secara intra-testikuler mempengaruhi luas struktur anekhoik. Semakin tinggi konsentrasi disinfektan yang diberikan maka semakin besar struktur anekhoik pada hasil pencitraan ultrasonografi. Hal tersebut ditunjukkan pada tampilan sonogram kelompok $\mathrm{C} 4$ yang memiliki struktur anekhoik lebih besar dibandingkan kelompok C2P5 dan C1P2. Senyawa disinfektan yang terdeposit dalam jaringan menyebabkan kerusakan jaringan testis. Inflamasi merupakan respon tubuh terhadap kerusakan jaringan (Abdurrahmat, 2014). Proses inflamasi menyebabkan permeabilitas pembuluh darah meningkat oleh histamin kemudian protein plasma keluar menuju ruang interstitial dan terjadi akumulasi cairan sekitar jaringan (Abdurrahmat, 2014). Menurut Azizah dan Batan (2018), akumulasi cairan pada hasil citra ultrasonografi ditunjukkan dengan warna anekhoik. 

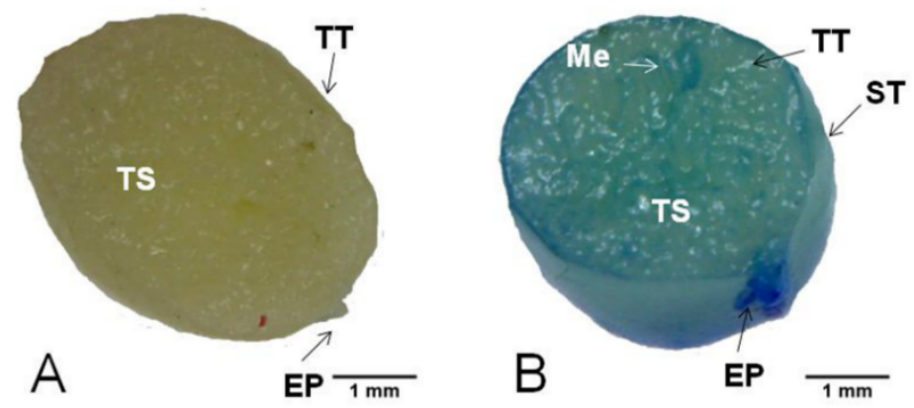

Gambar 3. Makroanatomi awetan testis kontrol. A) tanpa pewarnaan dan B) menggunakan pewarnaan Eosin Giemsa. $\mathrm{EP}=$ Epidisimis, $\mathrm{Me}=$ Mediastinum, $\mathrm{TT}=$ Tunika testis, $\mathrm{TS}=$ Tubulus seminiferus, $\mathrm{ST}=$ Septula testis.

Gambar 3 merupakan makroanatomi awetan testis kontrol dengan potongan transversal. Struktur internal jaringan awetan testis tanpa pewarnaan terlihat homogen sehingga bagianbagian testis sulit dibedakan, sedangkan struktur internal jaringan awetan testis dengan pewarnaan Eosin Giemsa terlihat jelas. Mediastium dan septula testis pada awetan testis tanpa pewarnaan tidak terlihat, sedangkan struktur internal lain seperti tubulus seminiferus, epididimis, dan tunika testis masih terlihat.

Giemsa merupakan pewarnaan polikromatik serbaguna yang cocok untuk pewarnaan beragam spesimen (Barcia, 2007). Struktur internal potongan testis tanpa pewarnaan terlihat homogen sehingga bagian-bagian testis sulit untuk dibedakan. Potongan awetan testis mencit yang dilakukan pewarnaan menggunakan eosin giemsa terlihat bagian-bagian internal testis yaitu mediastinum, tubuli seminiferus, septula testis, tunika testis dan epididimis. Struktur mediastinum terlihat bewarna biru tua, sedangkan sel-sel tubuli seminiferus terlihat berwarna biru pucat. Menurut Barcia (2007), pencampuran methylene azure dan methylene blue dalam giemsa yang membentuk eosin berfungsi untuk kestabilan hasil pewarnaan.

\section{Kesimpulan}

Kombinasi larutan disinfektan kloroxylenol $1,2 \%$ dan povidon iodin $2,5 \%$ memiliki daya hidup yang tinggi dan dapat merusak jaringan testis sehingga berpotensi sebagai bahan aktif untuk kastrasi kimiawi yang telah teruji pada mencit sebagai model untuk hewan ternak. Jenis larutan desinfektan tunggal dan konsentrasi tinggi yang digunakan memiliki daya hidup mencit yang rendah meskipun dapat menyebabkan kerusakan struktur testis yang lebih baik. Kerusakan jaringan testis akibat kastrasi kimiawi menyebabkan hewan menjadi steril atau infertil.

\section{Ucapan Terima Kasih}

Penulis mengucapkan terima kasih kepada Kementrian Riset, Teknologi dan Pendidikan Tinggi melalui Hibah Penelitian Unggulan Perguruan Tinggi (3/E1/KP.PTNBH/2019) atas sebagian pendanaan dalam penelitian ini. Penulis juga mengucapkan terima kasih kepada Rumah Sakit Hewan Pendidikan Fakultas Kedokteran Hewan Universitas IPB dan PT Karindo Alkestron untuk alat ultrasonografi (SonoDop S$3 \mathrm{XV}$ ) yang digunakan dalam penelitian ini.

\section{Daftar Pustaka}

Abdurrahmat, A. S. 2014. Luka, peradangan, dan pemulihan. Jurnal Entropi. 9(1):729-738.

Astawan, M., Wresdiyati, T., Arief, I. I., dan Suhesti, E. 2011. Gambaran hematologi tikus putih (Rattus norvegicus) yang diinfeksi Escherichia coli enteropatogenik dan diberikan probiotik. Media Peternakan. 34(1):3-17.

Auffray, C., Sieweke, M. H, and Geissmann, F. 2009. Blood monocytes: development, heterogeneity, and relationship with dendritic cells. Annual Review of Immunology. 27(1):669-692.

Awal, A. M., Rahman, M. M., Das, S. K., Siddiki, N. H., Kurohmaru, M., Bibin, A. B., and Hayashi, Y. 2004. Formalin affects the male 
reproduction of black bengal goats during prepubertal stage even at low concentration: In vivo study. Journal of Medicine Science. 4(1):84-89.

Azizah, H., dan Batan, I. W. 2018. Laporan kasus: Kistik endometritis pada kucing persia. Indonesia Medicus Veterinus. 7(2):177-184.

Barcia, J. J. 2007. The giemsa stain: Its history and applications. International Journal Surgical Pathology. 15(3):292-296.

Behm, C. A., and Ovington, K. S. 2000. The role of eosinophils in parasitic helminth infections: Insights from genetically modified mice. Parasitology Today. 16(5):202-209.

Botes, P., Mzibuko, A., and Viljoen, G. 2007. Animal Production. Afrika Selatan (RSA): Pearson Education.

Brahma, B., Sarkar, P., and Sarkar, U. 2016. Pchloro meta xylenol (PCMX) tolerant bacteria and their biodegradation. International Journal of Advancs in Science Engineering and Technology. 4(2):88-91.

Canpolat, I., Gur, S., Gunay, C., Bulut, S., and Eroksuz, H. 2006. An evaluation of the outcome of bull castration by intra-testicular injection of ethanol and calcium chloride. Revuede Medicine Veteriner. 8(9):420-225.

Colville, T., and Bassert, J. M. 2008. Clinical Anatomy dan Phisiology for Veterinary Technician. (US): Elsevier.

D'Hiru. 2013. Live Blood Analysis. Jakarta (ID): PT Gramdedia Pustaka Utama.

Destri, W. 2013. Studi histopatologi respon organ testis mencit (Mus musculus) terhadap potensi radioprotektif tanaman Rosela dalam radiasi ionisasi radiodiagnostik [skripsi]. Bogor (ID): Institut Pertanian Bogor).

Guivarc, M., Ordioni, U., Ahmed, H. M. A., Coben, S., Catherine, J. H., and Bukiet, F. 2017. Sodium hypochlorite accident: A systematic review. Journal of Endodontics. 43(1):16-24.

Guyton, A. C., and Hall, J. E. 2016. Fisiologi Kedokteraan. Edisi ke-12. Jakarta (ID): EGC.

Howe, L. M. 2006. Surgical methods of contraception and sterilization. Theriogenology. 66(3):500-509.
Ibrahim, A., Ali, M. M., Abou-Khalil, N. S., and Ali, M. F. 2016. Evaluation of chemical castration with calcium chloride versus surgical castration in donkeys: Testosterone as an endpoint marker. BioMed Central Veterinary Research. 12(46):2-9.

Izzaty, A., Dewi, N., dan Pratiwi, D. I. N. 2014. Ekstrak haruan (Channa striata) secara efektif menurunkan jumlah limfosit fase inflamasi dalam penyembuhan luka. Dentofasial. 13(3):176-181.

Jasper, R., Locatelli, G. O., Pilati, C., and Locatelli, C. 2012. Evaluation of biochemical, hematological and oxidative parameters in mice exposed to the herbicide glyphosate-roundup. Interdiscip Toxicol. 5(3):133-140.

Kannan, G., Terrill, T. H., Kouakou, B., Gazal, O. S., Gelaye, S., Amoah, E. A., and Samake, S. 2000. Transportation of goat: effects on physiological stress responses and live weight loss: Journal of Animal Science. 78(6):1450-1457.

[Kementan] Kementrian Pertanian. 2014. Pedoman Pembibitan Sapi Potong yang Baik. Direktorat Pembibitan Ternak (ID).

Kuswati, Ravenska, Hapsari, N., Yekti, A. P. A., dan Susilawati T. 2015. Pengaruh kastrasi terhadap performan produksi sapi persilangan Wagyu berdasarkan umur yang berbeda. Jurnal Ilmu-Ilmu Peternakan. 26(3):53-58.

Liesegang, T. J. 2002. Corneal endothelial cytotoxicity of diluted povidone-iodine. American Journal of Ophthalmology. 133(5):737.

Liu, E., and Fan, J. 2017. Fundamentals of Laboratory Animal Science. Boca Raton (US): CRC Press.

Malole, M. B. M, dan Pramono, C. S. U. 1989. Penggunaan Hewan-Hewan Percobaan di Laboratorium. Bogor (ID): IPB Pr.

Marquardt, C., Matuschek, C., Bolke, E., Gerber, P. A., Peiper, M., Seydlittz-Kurzbach, J. V., Buhren, B. A., Griensven, M. V., Budach, W., Hassan, M., Kukova, G., Mota, R., Hofer, D., Orth, K., and Fleischmann, W. 2010. Evaluation of the tissue toxicity of antiseptics by the hen's egg test on the chorioallantoic membrane (HETCAM). 
European Journal of Medical Research. 15(2):204-209.

Merck. 2007. The Merck/Merial Manual for Pet Health. Westford (US): Courier Westford.

McDonnell, G., and Russell, A. D. 1999. Antiseptics and disinfectans: Activity, action, and resistance. Clinical Microbiology Reviews. 12(1):147-179.

Mehdipour, O., Kleier, D. J., and Averbach, R. E. 2007. Anatomy of sodium hypochlorite accidents. Compendium of Continuing Education in Dentistry. 28(10):544-550.

Mohamed, A., and James, F. O. 2013. Chemical castration by a single bilateral intratesticular injection of chlorhexidine gluconate and cetrimide in bucks. Sokoto Journal of Veterinary Science. 11(1):62-65.

Moldave, K., and Rhodes, L. 2013. Contraception dan Fertility Control in Dogs and Cats. Portland (US): Alliance for Conception in Cats and Dogs.

Munaf, S. 2009. Kumpulan Kuliah Farmakologi. Jakarta (ID): EGC.

Murray, J. K., Mosteller, J. R., Loberg, J. M., Anderssonn, M., and Benka, V. A. W. 2015. Methods of fertility control in cats. Journal of Feline Medicine and Surgery. 17(9):790799.

Neto, O. A., Gasperin, B. G., Rovani, M. T., Ilha, G. F., Nobrega, J. E., Mondadori, R. G., Goncalves, P. B. D., and Antoniazzi, A. Q. 2014. Intratesticular hypertonic sodium chloride solution treatment as a method of chemical castration in cattle. Theriogenology. 82(7):1007-1011.

Noviana, D., Aliambar, S. H., Ulum, M. F., dan Siswandi, R. 2012. Diagnosis Ultrasonografi pada Hewan Kecil. Bogor (ID): IPB Pr.

Oliveira, F. C., Ferreira, C. E. R., Haas, C. S., Oliveira, L. G., Mondadori, R. G., Schneider, A., Rovani, M. T., Goncalves, P. B. D., Vieira, A. D., Gasperin, B. G., and Lucia, T. 2016. Chemical castration in cattle with intratesticular injection of sodium chloride: Effects on stress and inflammatory markers. Theriogenology. 90(1):114-119.

Opara, M. N., Udevi, N., and Okoli, I. C. 2010. Haematological parameters and blood chemistry of apparently healthy west african dwarf (wad) goats in Owerri, South Eastern
Nigeria. New York Science Journal. 3(8):6872.

Praharani, L., dan Sianturi, R. S. G. 2018. Tekanan inbreeding dan alternatif solusi pada ternak kerbau. Wartazoa. 28(1):1-12.

Purnawijayanti, H. A. 2001. Sanitasi Higiene dan Keselamatan Kerja dalam Pengolahan Makanan. Yogyakarta (ID): Kanisius.

Queiros, P., Santos, E., Apostolo, J., Cardoso, D., Cunha, M., and Rodrigues, M. 2014. The effectiveness of cleansing solutions for wound treatment: A systematic review. Journal of Biomedical Informatics. 12(10):121-151.

Ratnawati, D., Widyaningrum, Y., dan Sulistya, T. A. 2015. Perlakuan excercise pada sapi jantan PO terhadap peningkatan kualitas semen. Prosiding Seminar Nasional Teknologi Peternakan dan Veteriner. Bogor (ID): Puslitbangnak.

Restel, T. I., Porfirio, L. C., Souza, A. S. D., and Silva, I. S. 2014. Hematology of Swiss mice (Mus musculus) of both genders and different ages. Acta Cirurgica Brasileira. 29(5):306-312.

Sakamoto, H., Saito, K., Oohta, M., Inoe, K., Ogawa, Y., and Yoshida, H. 2007. Testicular volume measurement: Comparison of ultrasonography, orchidometry, and water dispalacement. Urology. 69(1):152-157.

Satria, M., Siregar, T. N., Sayuti, M., Melia, J., Hamdan, Rosmaidar, dan Harris, A. 2016. Estimasi jumlah anak yang lahir berdasarkan pemeriksaan ultrasonografi transcutaneus pada kambing kacang (Capra sp.). Jurnal Medika Veterinaria. 10(2):77-80.

Suckow, M. A., Danneman, P., and Brayton, C. 2001. The Laboratory Mouse. New York (US): CRC.

Susilorini, T. E., Sawitri, M. E., dan Maharlien. 2007. Budi Daya 22 Ternak Potensial. Bogor (ID): Penebar Swadaya.

Talib, C., Matondang, R. H., dan Herawati, T. 2011. Model pembibitan kambing dan domba di Indonesia. Prosiding Workshop Nasional Diversifikasi Pangan Daging Ruminansia Kecil. 55-63

Ulum, M. F., Paramitha, D., Sariningrum, A., Maharani, A. D. K., Tumbelaka, L. I. T. A., dan Noviana, D. 2017. Chemical castration 
using iron (III) chloride hexahydrate. Jurnal Veteriner. 18(3):360-368.

Utami, S. P., Mulyawati, E., dan Soebandi, D. H. 2016. Perbandingan daya antibakteri desinfektan instrumen preparasi saluran akar natrium hipoklorit 5.25\%, glutaraldehid $2 \%$, dan desinfektan berbahan dasar glutaraldehid terhadap Bacillus subtilis. Jurnal Kedokteran Gigi. 7(2):151-156.
Weiss, D. J., and Wardrop, K. J. 2010. Schalm's Veteinary Hematology. Ames (US): WileyBlackwell.

Widyastuti, D. A. 2013. Profil darah tikus putih wistar pada kondisi subkronis pemberian natrium nitrit. Journal of Veterinary Science. 31(2):201-215. 